\title{
Combined treatment with Sitagliptin and Vitamin D in a patient with Latent Autoimmune Diabetes of Adulthood
}

Eleni Rapti, Athanasios Mousiolis, Maria Grammatiki, Maria Yavropoulou, Pantelis Zebekakis, Michail Daniilidis, Kalliopi Kotsa

Department of Endocrinology and Metabolism, A' Internal Medicine Clinic, University General Hospital of Thessaloniki “AHEPA” - Greece

\section{OBJECTIVE}

To report a case of a patient diagnosed with Latent Autoimmune Diabetes of Adulthood (LADA) based on clinical presentation and positive Glutamic Acid decarboxylase antibodies (GAD-abs) that converted to antibody negative diabetes after combined treatment with sitagliptin and Vitamin D.

\begin{tabular}{|c|c|c|c|}
\hline & Feb/2013 & Jan/2014 & Feb/2015 \\
\hline$H b A 1 c$ & 9.6 & 5.4 & 5.2 \\
\hline GAD-abs & 32 & 4.2 & 4.1 \\
\hline $\begin{array}{c}25-O H-D 3 \\
n g / m L\end{array}$ & 11 & 41 & 39 \\
\hline $\begin{array}{c}\text { Cortizole } \\
\mu \mathrm{g} / \mathrm{dL}\end{array}$ & 16.9 & & \\
\hline$T S H \mu I U / m I$ & 1.01 & 1.3 & 1.21 \\
\hline $\begin{array}{l}\text { Insulin } \\
\mu I U / m I\end{array}$ & 10.3 & & 14 \\
\hline $\begin{array}{c}\text { C peptide } \\
n g / m I\end{array}$ & 1.0 & & 1.2 \\
\hline $\begin{array}{c}\text { Creatinine } \\
\mathrm{mg} / \mathrm{dl}\end{array}$ & 1.1 & 1.0 & 1.0 \\
\hline $\begin{array}{c}\text { Cholesterol } \\
\mathrm{mg} / \mathrm{dl}\end{array}$ & 241 & 198 & 195 \\
\hline $\begin{array}{c}\text { Triglycerides } \\
\mathrm{mg} / \mathrm{dl}\end{array}$ & 185 & 85 & 99 \\
\hline
\end{tabular}

A 31 year old Caucasian male presented at the emergency room with symptoms of polyuria, polydipsia and weight loss of approximately $15 \mathrm{~kg}$ during the previous three months. Blood glucose measured on site was $300 \mathrm{mg} / \mathrm{dl}$ with only traces of ketones in the urine, arterial blood gas within normal range (pH:7,36) and HbAlc at 9,6\%. He was a heavy smoker, overweight (Obesity Class I, BMI:32,8kg/m2) and had no prior medical history of serious or chronic medical conditions. He had a family history of autoimmune disorders as his sister had been diagnosed with type 1 diabetes mellitus (T1D) at the age of 5, an autoimmune haemolytic anaemia and autoimmune thyroiditis during puberty. Declining insulin therapy he was initially treated with gliclazide and metformin. A GADabs titer measurement was performed and the results came back positive at $32 \mathrm{U} / \mathrm{mL}$ $(\mathrm{NV}<5 \mathrm{U} / \mathrm{mL})$. A Human Leukocyte Antigens (HLA) genotyping for DR and DQ encoding loci was carried out and resulted in the genotype presented in Figure 2. Taking under consideration his age, the increased GAD-abs titer and the haplotype DQB1*02:01/03:02 which is positively associated with type 1 diabetes, a diagnosis of Latent Autoimmune Diabetes of Adulthood was established. Other blood tests came back normal except from a low $25-\mathrm{OH}-\mathrm{VitD}$ level of $11 \mathrm{ng} / \mathrm{mL}(\mathrm{NV}>30 \mathrm{ng} / \mathrm{mL}$ ) (Figure 1). Declining insulin therapy once again, he was advised to discontinue gliclazide and a combination of metformin $850 \mathrm{mg} /$ sitagliptin 50mg twice daily along with Vitamin D supplementation (2000 IU/day) was prescribed.

Figure 3

\begin{tabular}{|l|l|l|l|}
\hline HLA-DRB1* & $04: 01 /$ & $03: 01 /$ \\
\hline HLA-DQB1* & $02: 01 /$ & $03: 02 /$ & \\
\hline
\end{tabular}

\section{RESULTS}

Being able to comply with diet and exercise directions he presented 6 months later with an excellent glycemic profile and HbAlc of $6,1 \%$. At 11 months his $\mathrm{HbAlc}$ was $5,4 \%$ and his GAD-abs level declined by $86 \%$ within normal range at $4,2 \mathrm{U} / \mathrm{mL}$ (Figure 3 ). Two years later, receiving the same treatment, he has negative GAD-abs, his $\mathrm{HbAlc}$ is $5,2 \%$ and he maintains an excellent glycemic profile (Figure 1).

\section{CONCLUSIONS}

Both Vitamin D analogues and Dipeptidyl peptidase-4 (DPP-4) inhibitors have been shown to improve $\beta$-cell function and attenuate autoimmunity in type 1 diabetic mouse models. To our knowledge this is the first case that combined treatment with sitagliptin and Vitamin D in a patient with LADA reverted the phenotype and preserved an excellent glycemic control without the use of insulin 24 months after diagnosis.

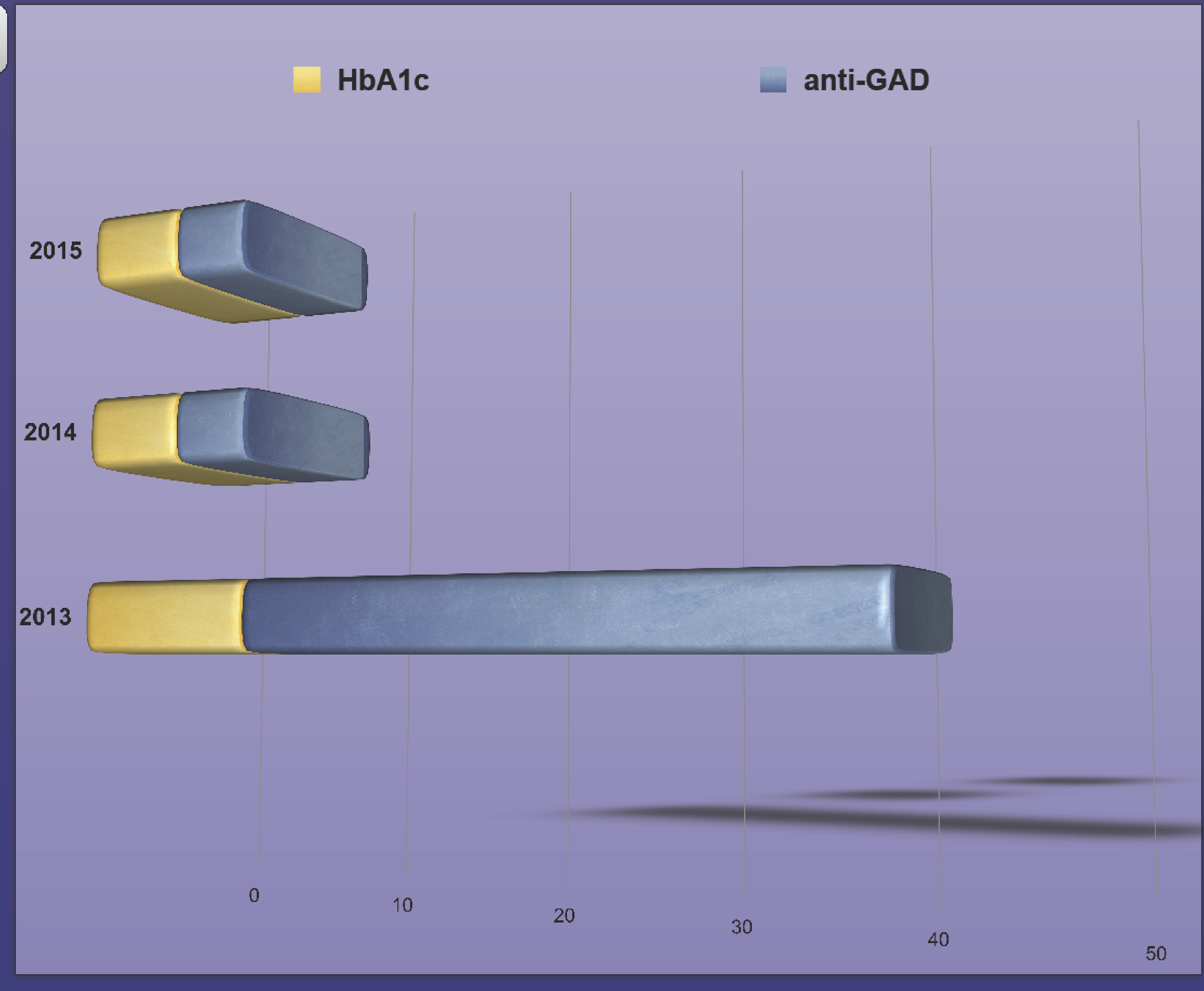

\section{REFERENCES:}

1. Lima-Martinez MM, Guera-Alcala E, Contreras M, Nastasi J, Noble JA, with sitagliptin. Endocrinol Diabetes Metab Case Rep. 2014;2014:140072

2. Pozzili P, Mario UD. Autoimmune diabetes not requiring insulin at diagnosis (Latent autoimmune diabetes of adult). Diabetes Care. 2001;24:1460-67

3. Kandasamy N, Lennox G, Annamalai AK, Maguire G, Adler AI. Sitagliptin in glutamic acid decarboxylase antibody-positive diabetes mellitus. Endocr Pract. 2012;18:65-8

4. Hayes CE, Hubler SL, Moore JR, Barta LE, Praska CE, Nashold FE. Vitamin D actions on CD4(+) T cells in autoimmune disease. Front Immunol. 2015;6:100 Polychronakos C. One year remission of type 1 diabetes mellitus in a patient treated 